\title{
10. PETROGRAPHY OF VOLCANIC ASHES IN DEEP-SEA CORES NEAR JAN-MAYEN ISLAND: SITES 338, 345-350 DSDP LEG 38
}

\author{
Arthur G. Sylvester, Department of Geological Sciences and Marine \\ Science Institute, University of California, Santa Barbara, California
}

\section{INTRODUCTION}

The purpose of this study is to determine the petrographic characteristics of volcanic ashes in deep-sea cores obtained from DSDP drill cores near Jan-Mayen Island. The ultimate objective is to work out, if possible, a more complete volcanic history of the island than is known from subaerial field studies of the island itself (Fitch, 1964).

Forty-six samples of volcanic ashes were collected for this study by the shipboard party of Glomar Challenger from seven of the Leg 38 drill sites. The locations of the sites with respect to Jan-Mayen are shown in Figure 1. The samples range in age from late Eocene to Pleistocene; the sampled intervals are shown in Figure 2

\section{METHODS AND TERMINOLOGY}

All samples were studied optically in whole-rock smear slides with a Caedex mounting medium, and in $\mathrm{X}$-ray diffraction patterns of whole-rock powders. Percentages of constituents were estimated from the smear slides and are approximate.

The problems inherent in identification and estimation of the amounts of constituents in volcanic ashes have been discussed by Donnelly (1975); however, the constituents of most samples in this study are remarkably fresh, so that alteration poses only minor problems.

Sampling was not comprehensive and coring was not continuous at all sites (Figure 2); thus a complete volcanic record cannot be established at this time for individual sites, and correlations among sites are virtually precluded. Future studies will include acquisition of material from other ash beds from these sites, as well as chemical characterization of glass and selected mineral phases with an electron microprobe.

The terminology and genetic interpretations in the following sections follow those given by Heiken (1975). Age assignments are taken from the Initial Core Descriptions compiled for Leg 38.

\section{PETROGRAPHY}

Nearly all samples consist of well-sorted, finegrained, highly angular basaltic and felsitic glass and mineral fragments. They suggest an explosive hydrovolcanic origin and dispersal as wind-borne rather than pumice- or ice-rafted debris. The ashes and their altered products can be separated broadly into three types: basaltic ash, felsitic ash, and bimodal basaltic and felsitic ash.

The constituents in the two samples of middle Oligocene age from the outer V $\phi$ ring Plateau (Site 338) and in the three samples of Oligocene and late Eocene age from the Lofoten Basin (Site 345) are dissimilar to each other and to those from the other sites. The differences probably reflect different sources. The constituents of all samples are given in Table 1. Representative textures are shown in Plate 1.

\section{Black Glass}

Tachylyte (submicrocrystalline opaque black glass of basaltic composition) is ubiquitous in all basaltic and basaltic-felsitic ashes. The grains are blocky, equant to irregularly polygonal in shape, with rounded corners and hackly surfaces. In a few samples, the surfaces of tachylyte grains are liberally sprinkled with tiny (1-2 $\mu \mathrm{m})$ pyrite rhombs. Rarely are microphenocrysts imbedded or attached to the grains. Grain sizes range from about $50 \mu \mathrm{m}$ to $600 \mu \mathrm{m}$; from $100 \mu \mathrm{m}$ to $200 \mu \mathrm{m}$ is average.

\section{Brown Glass}

Sideromelane (light- to dark-brown translucent volcanic glass of basaltic composition) is present in most basaltic and basaltic-felsitic ashes (Table 1). It has a refractive index greater than Caedex. Commonly the grains are blocky, subequant or irregular polygonal fragments with smooth conchoidal fracture surfaces; the glass is homogeneous; microlites are rare; and vesicularity ranges from low to moderate. All of these features are characteristic of hyaloclastic ashes of hydrovolcanic eruptions (Heiken, 1975). Round droplets, indicative of a subaerial magmatic origin, are present, sparingly, in some of the basaltic-felsitic ashes (348-6-4, $46 \mathrm{~cm} ; 348-6-4,75 \mathrm{~cm} ; 348-8-1,145 \mathrm{~cm}$; 348-82 , $30 \mathrm{~cm} ; 348-9-4,76 \mathrm{~cm} ; 349-1-1,63 \mathrm{~cm} ; 349-2-4,75$ $\mathrm{cm} ; 350-10-3,12 \mathrm{~cm} ; 350-10-3,39 \mathrm{~cm} ; 350-12-3,25 \mathrm{~cm}$ ), and exclusively in $349-2-5,55 \mathrm{~cm}$ (Plate 1, Figure 5).

Sideromelane is strongly altered in samples of late Oligocene and older ages; it is partially palagonitized in $346-4-5,128 \mathrm{~cm}$ and in $346-8-5,38 \mathrm{~cm}$.

\section{Clear Glass}

Clear isotropic glass has a refractive index less than Caedex, indicating a rhyolitic, or more broadly, felsitic composition. At sites on the Jan-Mayen Ridge and the Icelandic Plateau, it is present chiefly as water-clear, nonporphyritic, highly angular, irregularly shaped platelets ranging in size from about $50 \mu \mathrm{m}$ to as much as $800 \mu \mathrm{m}$ in maximum dimension. Typically less than half of the clear glass is pumiceous, with highly streaked bubbles. Black spherulites about $5 \mu \mathrm{m}$ in diameter speckle the surfaces of blocky grains in $348-7-3,37 \mathrm{~cm}$. The glass in samples from the outer V $\phi$ ring Plateau (Site 338 ) is quite fine grained (average $50 \mu \mathrm{m}$ ), and less 


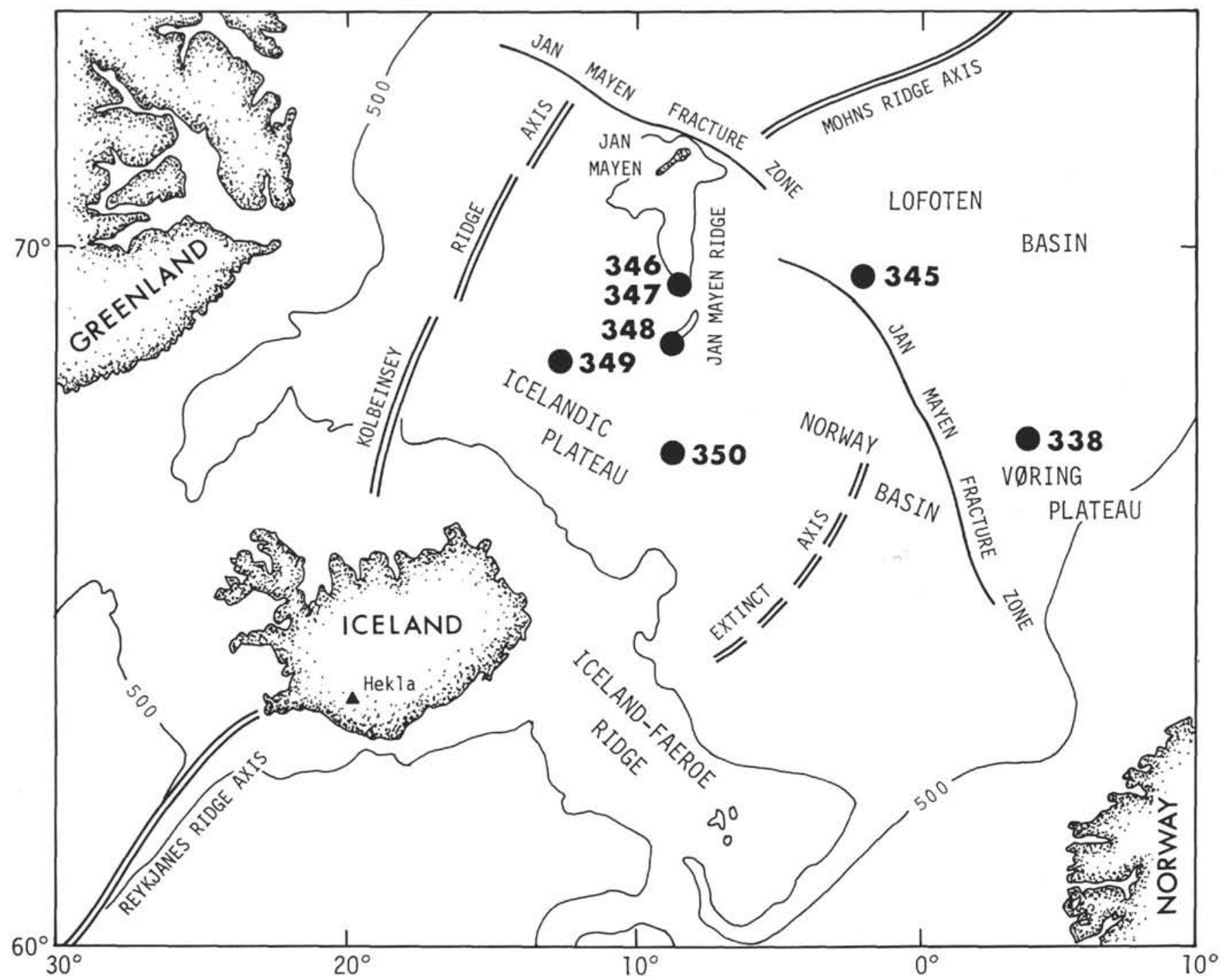

Figure 1. Index map showing locations of DSDP drill sites and principal tectonic elements of the Norwegian-Greenland Sea. Submarine contours are in fathoms. Adapted from Initial Core Descriptions for Leg 38.

than one-fourth of the grains are pumiceous (Plate 1, Figure 1).

\section{Microcrystalline Glass}

Clear glass with a pale brown turbidity in transmitted light and which is charged with tiny, lath-shaped microphenocrysts visible under crossed polarizers is abundantly present in basaltic-felsitic ashes containing otherwise undevitrified sideromelane, tachylite, and clear glass (Table 1). Its index is less than Caedex and is present in equant subrounded grains equivalent in size to that of the other glass constituents. The tinge of color suggests that it is intermediate in composition between the basaltic glasses and the more common clear, isotropic glass.

\section{Plagioclase}

Plagioclase crystal fragments and euhedral microphenocrysts comprise minor fractions (usually less than $1 \%$ ) of all samples with two notable exceptions: 1) at Site 345 , subhedral lath-shaped crystals up to $500 \mu \mathrm{m}$ in length constitute as much as $30 \%$ of the ash sample (Plate 1, Figure 2), and 2) euhedral plagioclase phenocrysts up to $300 \mu \mathrm{m}$ long constitute approximately $15 \%$ of Sample $348-8-2,3 \mathrm{~cm}$, and $10 \%$ and $8 \%$, respectively, of samples directly beneath. These plagioclaserich samples are provisionally correlated with a unique plagioclase-rich lava on Jan-Mayen as will be described later. Plagioclase in basaltic ashes have broader twin lamellae and higher refractive indices (equal to or slightly less than Caedex) than those in felsitic and basaltic-felsitic ashes.

\section{Clinopyroxene}

Subhedral to anhedral crystal fragments of clinopyroxene constitute from a trace to as much as $2 \%$ of basaltic and basaltic-felsitic ashes from sites on the JanMayen Ridge and Icelandic Plateau (Table 1). It is invariably pale green to pale brownish green, nonpleochroic, and has a refractive index much greater than Caedex. The grains are equant with conchoidal fracture surfaces, and are rarely larger than $300 \mu \mathrm{m}$ in the longest dimension.

\section{Orthopyroxene}

A few rectangular prisms of orthopyroxene were identified in only two samples $(348-6-5,30 \mathrm{~cm} ; 348-8-3$, $131 \mathrm{~cm}$ ). They are readily distinguished by the distinc- 
Icelandic Plateau - Jan Mayen Ridge

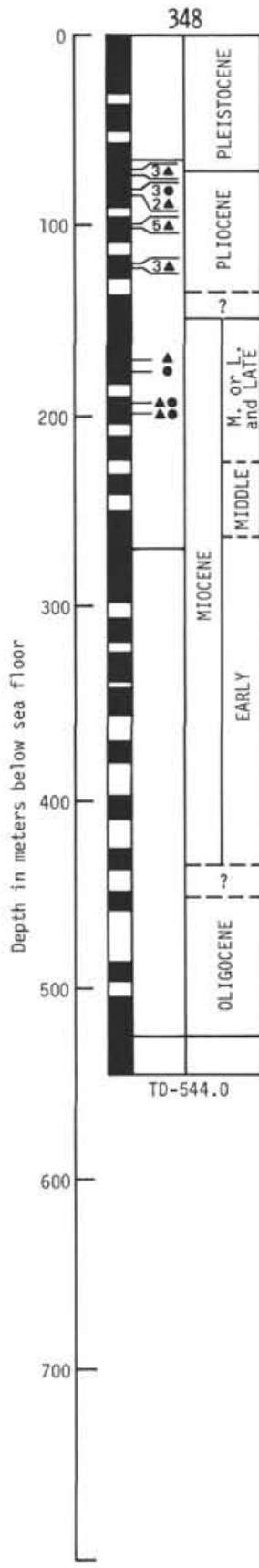

SYMBOLS:

$\Delta$ basaltic glass

- felsitic glass

A. basaltic and felsitic glass
Lofoten Basin

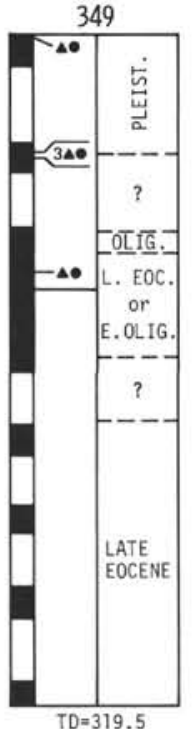

2 two samples from cored interval
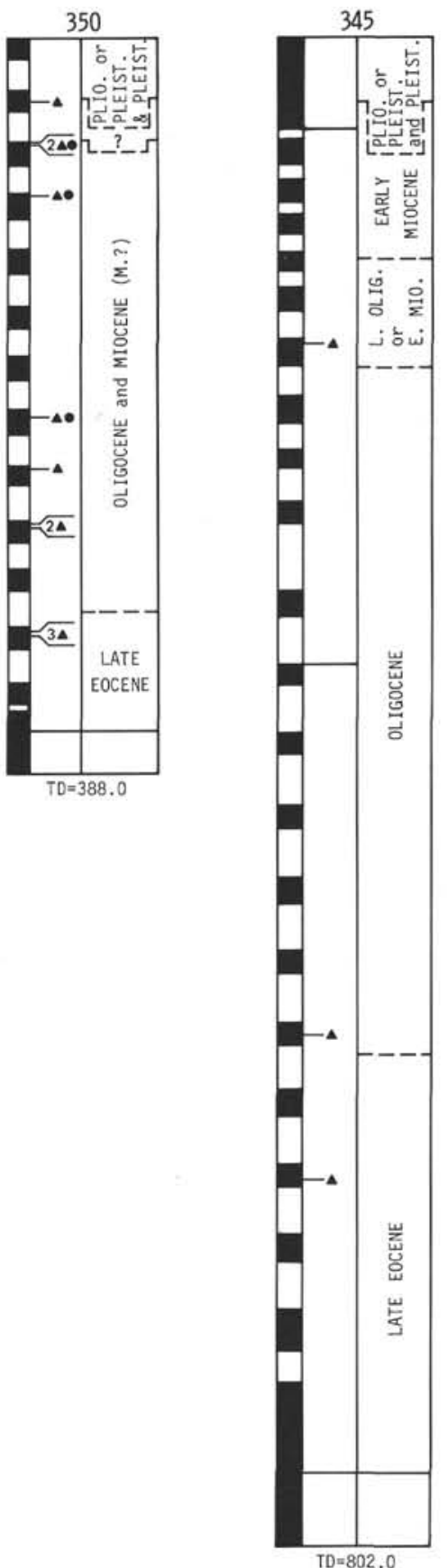

Outer Vøring Plateau

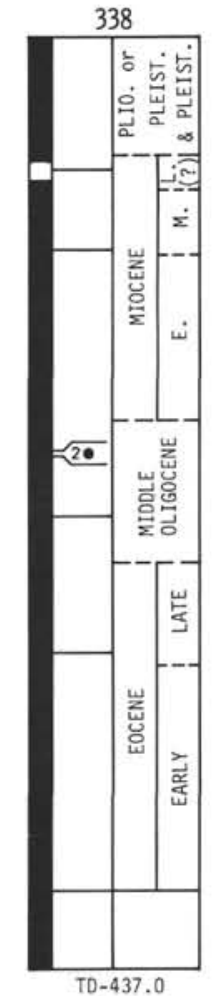

Figure 2. Diagrammatic columnar sections showing sampled intervals for this study, number of samples for given interval, and predominant lithologic type of ash. Adapted from Talwani et al. (1975).

tive pink-blue-green pleochroism and straight extinction. The prisms range in length from $100 \mu \mathrm{m}$ to 200 $\mu \mathrm{m}$.

\section{Biotite}

Biotite is present exclusively and abundantly only in samples from Cores 21 and 23 of Site 345 (Plate 1, Figure 2). Predominantly basal sections of the mineral were observed, owing to the smear method of slide preparation, but its presence is confirmed in X-ray powder diffraction patterns. It is distinguished in thin section from coexisting tachylyte by its subhedral crystal form, its faint translucence in transmitted light, and by its birefringence in grains that are not oriented perfectly normal to the microscope axis. Cleavage platelets are subequant, and are approximately from $150 \mu \mathrm{m}$ to $200 \mu \mathrm{m}$ across.

\section{Hornblende}

A few tiny (50 $\mu \mathrm{m}$ to $80 \mu \mathrm{m})$ crystal fragments tentatively identified as hornblende, are present in four ash samples (Table 1). They are lath-shaped with irregular 
TABLE 1

Constituents Distinguished in Volcanic Ash Samples from Deep-Sea Cores: Sites 338, 345-350, DSDP Leg 38

\begin{tabular}{|c|c|c|c|c|c|c|c|c|}
\hline $\begin{array}{c}\text { Sample } \\
\text { (Interval } \\
\text { in } \mathrm{cm} \text { ) }\end{array}$ & Age & $\begin{array}{c}\text { Tachylite } \\
(\%)\end{array}$ & $\begin{array}{c}\text { Sideromelane } \\
(\%)\end{array}$ & $\begin{array}{c}\text { Clear } \\
\text { Glass } \\
(\%)\end{array}$ & $\begin{array}{l}\text { Micro- } \\
\text { crystalline } \\
\text { Glass } \\
(\%)\end{array}$ & $\begin{array}{l}\text { Plag } \\
(\%)\end{array}$ & $\begin{array}{c}\text { Clpx } \\
(\%)\end{array}$ & Other \\
\hline
\end{tabular}

Site 338: Outer Vøring Plateau

$\begin{array}{ll}20-3,54 & \text { M. Olig. } \\ 20-3,100 & \text { M. Olig. }\end{array}$

Site 345: Western Lofoten Basin

11-1, $33 \quad$ L. Olig. or E. Mio.

$21-4,77$

Oligocene

23-6, 86

L. Eocene

5
25

25
25

$80 \mathrm{~A}$

10

Site 346: Northern Jan-Mayen Ridge

$\begin{array}{ll}4-5,128 & \text { M. Miocene (?) } \\ 8-5,38 & \text { M. Miocene }\end{array}$

14-4, 14 Eocene(?)

20
30
25

$60 \mathrm{~A}$
13
$50 \mathrm{~A}$

10
50

Site 347: Northern Jan-Mayen Ridge

$$
\begin{array}{r}
3-3,100 \\
3-3,148
\end{array}
$$

Eocene

Eocene

10
15

$80 \mathrm{~A}$

$55 \mathrm{~A}$

85

85

Site 349: Central Jan-Mayen Ridge

$\begin{array}{llr}1-1,63 & \text { Pleistocene } & 15 \\ 2-3,60 & \text { Pleistocene } & 5 \\ 2-4,75 & \text { Pleistocene } & 30 \\ 2-5,55 & \text { Pleistocene } & 53 \\ 5-3,73 & \text { E. Oligocene or } & 30 \\ & \text { L. Eocene }\end{array}$

Site 348: Icelandic Plateau

$\begin{array}{lll}6-4,46 & \text { Pleistocene } & 3 \\ 6-4,75 & \text { Pleistocene } & 4 \\ 6-5,30 & \text { Pliocene } & \\ 7-3,37 & \text { Pliocene } & \\ 7-4,48 & \text { Pliocene } & \\ 7-4,114 & \text { Pliocene } & 6 \\ 7-5,91 & \text { Pliocene } & 5 \\ 7-5,131 & \text { Pliocene } & 3 \\ 8-1,145 & \text { Pliocene } & 3 \\ 8-2,3 & \text { Pliocene } & 5 \\ 8-2,30 & \text { Pliocene } & 7 \\ 8-2,52 & \text { Pliocene } & \\ 8-3,114 & \text { Pliocene } & 2 \\ 8-3,131 & \text { Pliocene } & 1 \\ 9-4,41 & \text { Pliocene } & 3 \\ 9-4,76 & \text { Pliocene } & 1 \\ 9-5,129 & \text { Pliocene } & \\ 13-1,105 & \text { L. Miocene } & \\ 13-3,140 & \text { L. Miocene } & \\ 14-3,60 & \text { L. or M. Miocene } & 1 \\ 14-5,110 & \text { L. or M. Miocene } & 6 \\ & & \end{array}$

Site 350: Southern Jan-Mayen Ridge

\begin{tabular}{lll}
$2-5,10$ & Plio. or Pleistocene & 35 \\
$3-1,110$ & M. Miocene & 3 \\
3, CC & M. Miocene & 4 \\
$4-1,2$ & Undated & 40 \\
$8-3,149$ & Oligocene (?) & 4 \\
$9-2,97$ & Oligocene & 35 \\
$10-3,12$ & Oligocene & 3 \\
$10-3,39$ & Oligocene & 40 \\
$12-3,25$ & L. Eocene & 35 \\
$12-3,39$ & L. Eocene & 50 \\
$12-3,134$ & L. Eocene & 35 \\
\hline
\end{tabular}

Note: A indicates constituent is altered.

75

$49 \mathrm{~A}$

$40 \mathrm{~A}$

25
20

\begin{tabular}{|c|c|c|c|c|c|c|}
\hline \multirow{3}{*}{$\begin{array}{l}30 \\
40\end{array}$} & 15 & 55 & & $\operatorname{tr}$ & $\operatorname{tr}$ & Py \\
\hline & 25 & 35 & & $\operatorname{tr}$ & $\operatorname{tr}$ & Py \\
\hline & $90 \mathrm{~A}$ & & & 7 & & Qtz (3), green $\mathrm{Hb}$ \\
\hline & $10 \mathrm{~A}$ & 65 & 25 & $\operatorname{tr}$ & & \\
\hline & & 48 & 48 & 3 & & Py (1) \\
\hline & $2 \mathrm{~A}$ & 45 & 50 & 3 & & \\
\hline 60 & 35 & & & 4 & 1 & \\
\hline $\begin{array}{l}50 \\
35\end{array}$ & 45 & & & 4 & 1 & \\
\hline $\begin{array}{l}35 \\
35\end{array}$ & $60 \mathrm{~A}$ & & & 3 & 2 & \\
\hline 35 & $50 \mathrm{~A}$ & & & 15 & $\operatorname{tr}$ & \\
\hline 50 & $40 \mathrm{~A}$ & & & 10 & $\operatorname{tr}$ & \\
\hline 75 & 5 & & & 8 & 2 & Py (10) \\
\hline & & 92 & 5 & 3 & & \\
\hline $\begin{array}{l}20 \\
10\end{array}$ & $70 \mathrm{~A}$ & 10 & & $\operatorname{tr}$ & $\operatorname{tr}$ & Orpyx \\
\hline $\begin{array}{l}10 \\
37\end{array}$ & $90 \mathrm{~A}$ & & & tr & $\operatorname{tr}$ & \\
\hline $\begin{array}{l}37 \\
10\end{array}$ & $60 \mathrm{~A}$ & $\begin{array}{r}5 \\
60\end{array}$ & 20 & 2 & 1 & \\
\hline 5 & $\begin{array}{l}28 \mathrm{~A} \\
95 \mathrm{~A}\end{array}$ & 60 & 20 & $\operatorname{tr}^{1}$ & 1 & \\
\hline & & 80 & & & & Clay (20) \\
\hline 15 & $80 \mathrm{~A}$ & 5 & & $\operatorname{tr}$ & & \\
\hline 65 & 15 & 10 & & 10 & & Clay, py \\
\hline 35 & 15 & 50 & & $\operatorname{tr}$ & & Olivine (?) \\
\hline 35 & 60 & 5 & & tr & & \\
\hline 40 & $50 \mathrm{~A}$ & 7 & & 3 & & Green clay \\
\hline $\begin{array}{l}40 \\
40\end{array}$ & $50 \mathrm{~A}$ & 10 & & tr & & \\
\hline $\begin{array}{l}40 \\
35\end{array}$ & & 45 & & 5 & & Py $(10$, Green clay \\
\hline 30 & $40 \mathrm{~A}$ & & & $\operatorname{tr}^{2}$ & & $\begin{array}{l}\text { Py (3), Qtz, Calcite (40) } \\
\text { Calcite }(30)\end{array}$ \\
\hline 40 & $50 \mathrm{~A}$ & & & $\operatorname{tr}$ & & Clay (10) \\
\hline 35 & $55 \mathrm{~A}$ & & & $\operatorname{tr}$ & & Py (10), Clay \\
\hline 50 & $50 \mathrm{~A}$ & & & tr & & Py, Clay \\
\hline 35 & $60 \mathrm{~A}$ & & & 5 & & Py, Clay \\
\hline
\end{tabular}

5

48
Clay (20)

Clay, py

Py $(10$, Green clay

Py (3), Qtz, Calcite (40)

Py, Clay
Py (12), green $\mathrm{Hb}$ Py (12), green $\mathrm{Hb}$

Dk brn Bi (15)

Dk brn Bi (10), $\mathrm{Zr}$

$\begin{array}{lll}30 & 20 & \text { Dk brn Bi (15) } \\ 35 & 25 & \text { Dk brn Bi (10), Zr }\end{array}$

$12 \quad 3$

Qtz (7), Chlor, Microcline Qtz (15), Chlor, green $\mathrm{Hb}$

$\begin{array}{rrrl}60 & \text { tr } & \text { tr } & \text { Qtz (tr) } \\ & 3 & & \text { Qtz (2) } \\ & 1 & \text { tr } & \text { Qtz (tr), grn Clay } \\ 2 & \text { tr } & \text { Qtz (tr) } \\ & 7 & & \text { Qtz (tr), Py (15) }\end{array}$

Py (5)

Qtz (20), Chlor

Qtz (tr), Py (15) 
terminations, dark green in color, and extinguish in polarized light at moderately low angles to the elongation. The refractive index is greater than Caedex.

\section{Calcite}

Fine-grained calcite constitutes as much as $30 \%$ of samples in Core 9, and in the younger of the two samples in Core 10 from Site 350 . However, it is completely lacking in all other samples.

\section{Quartz}

Small, irregularly shaped crystal fragments of quartz are sparingly present in basaltic ashes from Sites 346 and 347 . It is probably detrital.

\section{Opaque Minerals}

Pyrite, magnetite (titanomagnetite?), and hematite are the only opaque minerals observed Magnetite and hematite, which has formed by oxidation of magnetite, together rarely constitute more than $1 \%$ of any of the samples. Pyrite, however, constitutes from 0 to $5 \%$, and is abundantly present both in samples from Site 338 and in Core 8-2 (Plate 1, Figure 1), from Site 348 . In the latter samples, the surfaces of tachylyte and sideromelane grains are almost covered by tiny (1-2 $\mu \mathrm{m})$ pyrite rhombs.

\section{Clays}

X-ray diffractograms show that clay minerals are abundant in a few samples, particularly those that are most strongly devitrified (Table 1). No attempt was made at this time to identify the clay minerals.

\section{Biogenic Components}

Sponge spicules, diatoms, radiolarians, and silicoflagellates are present, sparingly to abundantly, in samples ranging in age from middle Miocene to Pleistocene at sites on the Icelandic Plateau and Jan-Mayen Ridge. Traces of radiolarians are present in ash from Site 338; ash samples from Lofoten Basin (Site 345) are barren.

\section{DISCUSSION}

\section{Transportation and Deposition}

The highly fragmented, blocky grain morphology and low vesicularity of basaltic glasses indicate that most of the ash samples are products of hydrovolcanic eruptions. This is a typical mode of eruption for basaltic magmas in the Iceland region as shown not only by the recent eruptive activity of Surtsey (Thorarinsson, 1967a, b), but also by the petrography of basaltic tuffs of Glacial age, the bulk of which were erupted from beneath a thick glacial ice cap (Kjartansson, 1967). According to Heiken (1975), hydrovolcanic eruptions are caused when hot magma encounters and is suddenly quenched by ground water, seawater, or glacial meltwater, resulting in violent steam eruptions and consequent fragmentation of glass, crystals, and lithic inclusions. In explosive magmatic eruptions, the ascending magma is turned into a froth by rapid expansion of coalescing gas bubbles exsolving from the magma; this yields, upon eruption, droplets and pasty clots of magma whose shapes are controlled by the combined effects of surface tension, acceleration, and air resistance.

The well-sorted character of all the ash samples suggests dispersal as wind-borne, rather than pumicerafted, debris. Because this region of the sea is commonly covered by pack ice during much of the year, it is also possible that some of the ashes were temporarily deposited on a raft of sea-ice before ultimate deposition upon the sea floor. Such a process may have delayed the deposition of ash for as long as a year or so, but hardly longer. Because of the relatively high frequency of eruptive activity in this region, one would expect that ashes from several lithologically distinct and geographically separate volcanic centers could have accumulated together over a period of years upon the ice, only to be mixed during settlement to the sea floor when the ice melted. In such cases, the ashes in deep-sea sediments should be rather poorly sorted, in contrast to those of this study. Without chemical data to establish that these ashes represent mixtures from separate volcanic centers, it seems reasonable to conclude that ice rafting has not played a significant or at least, detectable, role in the depositional history of these ashes.

Aeolian differentiation may be invoked to account for the lack of olivine or its alteration products in these remarkably fresh ashes, as well as the relatively low amount of magnetite. Both of these heavy minerals are common in basalts in Iceland and Jan-Mayen, which are the two most likely source areas for these ashes.

Pyrite, which is abundantly present in some of the samples, may be authigenic in origin, but alternatively, it may be primary, having been deposited on the surfaces of grains by sublimation from the eruption cloud during atmospheric transport. This hypothesis is suggested by the report of pyrite-covered sulfur droplets in the recent fine-grained wind-borne ejecta from Mt. Baker, Washington (David Frank, University of Washington, personal communication, 20 June, 1975).

\section{Correlation and Sources}

Correlation of specific ash layers among the drill sites is precluded at this time by the fact that not all of the encountered volcanic ash layers were sampled for this preliminary study, by the lack of forthcoming chemical analyses of the ashes, and by the gross nature of the available paleontologic age assignments for the sampled intervals.

Some of the ashes may be correlated provisionally with probable sources, however, particularly those of late Cenozoic and Recent ages from the Icelandic Plateau and Jan-Mayen Ridge (Sites 346, 347, 348, 349, and 350 ). These ashes are petrographically similar to volcanic rocks of comparable ages in the nearby volcanic centers of Iceland and Jan-Mayen. However, the few samples of early Cenozoic age from the outer V $\phi$ ring Plateau (Site 338) and the Lofoten Basin (Site 345) differ so markedly from one another and from those of the other sites (Table 1) that it is reasonable to conclude that they were derived from separate and, as yet, unknown sources.

The most likely sources of ashes on the Icelandic Plateau-Jan-Mayen Ridge are Iceland and Jan-Mayen 
Island which have well-documented records of volcanic activity throughout late Cenozoic and Recent times. It is also possible that some of the material may have originated from presently submerged portions of the Kolbeinsey and Mohns ridges, perhaps even the Iceland-Faeroe Ridge. However, this will be difficult to establish with the available data.

The felsitic ashes almost certainly originated from volcanic centers in Iceland where about $10 \%$ of the exposed volcanic rocks are acidic and intermediate lavas and pyroclastic deposits. Hekla (Figure 1), for example, is one of six central volcanoes in Iceland characterized by eruption of acidic and intermediate lava and tephra in addition to the more preponderant volumes of basalt (Sigurdsson, 1967). Thorarinsson (1967a, b) has shown that windborne tephra from several historic eruptions of Hekla has been carried northward across Iceland toward Jan-Mayen Island. Moreover, the tephra is often composite, composed of rhyolitic ash from an initial Plinian explosive phase followed by eruption of intermediate lava and tephra. Such an eruptive cycle may account for the mixture of felsitic and basaltic glass in the bimodal ashes of this study, as well as the presence of ash of intermediate (?) composition in some of the samples.

The clinopyroxene-bearing basaltic ashes, all but one of which are Pliocene or Pleistocene in age, were probably derived from Jan-Mayen Island where clinopyroxene, specifically chromian diopside and salite (Hawkins and Roberts, 1972; Weigand, 1972), is a characteristic mineral phase in the ankaramitic basalts and trachybasalts that comprise most of the subaerial portion of the island. However, it is lacking or rare in most Icelandic volcanic rocks (S. Jakobsson, written communication, 1975).

Of particular interest are the modal variations in the sequence of clinopyroxene-bearing basaltic ashes in Cores 7 and 8 of Site 348 (Table 1), because they are very similar to the general modal variations among lavas of comparable age on Nord Jan. There predominantly ankaramitic lavas of the Nordvestkapp and Troms $\phi$ ryggen formations are separated by the Sentralkrater Formation, a distinctive glomeroporphyritic plagioclase basalt (Fitch, 1964), and the only one of its kind known on Jan-Mayen. Ash Samples 348-8-2. 3. 30, and $52 \mathrm{~cm}$ are rich in plagioclase phenocrysts in contrast to all other samples of comparable age of this study, and for this reason they are provisionally correlated with the Sentralkrater Formation. If this correlation is confirmed by chemical analyses, it indicates that the subaerial portion of Jan-Mayen Island is at least as old as early (?) Pliocene, which is somewhat older than suggested by radiometric ages (Fitch et al., 1965), or volume-eruption frequency calculations (Sylvester, 1975).

\section{REFERENCES}

Donnelly, T.W., 1975. Neogene explosive volcanic activity of the western Pacific: Sites 292 and 296, DSDP Leg 31. In Ingle, J.C., Karig, D.E., et al., Initial Reports of the Deep Sea Drilling Project, Volume 31: Washington (U.S. Government Printing Office), p. 557-597.

Fitch, F.J., 1964. The development of the Beerenberg volcano, Jan Mayen: Geol. Assoc. Proc., v. 75, p. 133-165.

Fitch, F.J., Grasty, D.L., and Miller, J.A., 1965. Potassiumargon ages of rocks from Jan Mayen and an outline of its volcanic history: Nature, v. 207, p. 1349-1351.

Hawkins, T.R.W. and Roberts, B., 1972. The petrology of the volcanic and intrusive rocks of Nord Jan, Jan Mayen. Norsk Polarinst. Årbok for 1970, p. 19-41.

Heiken, G., 1975. An atlas of volcanic ash: Smithsonian Contrib. Earth Sci., No. 12, p. 1-101.

Kjartansson, G., 1967. Volcanic forms at the sea bottom. In Björnsson, S. (Ed.), Iceland and mid-ocean ridges: Rept. Symp. Soc. Sci. Islandica, v. 38, p. 53-56.

Sigurdsson, H., 1967. The Icelandic basalt plateau and the question of sial: a review. In Björnsson, S., (Ed.), Iceland and mid-ocean ridges: Rept. Symp. Soc. Sci. Islandica, v. 38 , p. $32-49$.

Sylvester, A.G., 1975. History and surveillance of volcanic activity on Jan Mayen Island.

Talwani, M. et al., 1975. Leg 38: Geotimes, v. 2, p. 24-26.

Thorarinsson, S., 1967a. Hekla and Katla: The share of acid and intermediate lava and tephra in the volcanic products through the geological history of Iceland. In Björnsson, S., (Ed.), Iceland and mid-ocean ridges: Rept. Symp. Soc. Sci. Islandica, v. 38, p. 190-199.

Thorarinsson, S., 1967b. The eruptions of Hekla in historical times: A tephrochronological study. In The eruption of Hekla 1947-1948: Reykjavik (Soc. Sci. Islandica).

Weigand, P.W., 1972. Bulk-rock and mineral chemistry of Recent Jan Mayen basalts: Norsk Polarinst. Årbok for 1970 , p. $42-52$. 



\section{PLATE 1}

Representative textures of volcanic ashes. Plane light.

Bar scale is $100 \mu \mathrm{m}$ long.

Figure $1 \quad$ Vitric felsitic ash. Very fine grained, platy felsitic glass shards and cubiform pyrite. Middle Oligocene; Outer V $\phi$ ring Plateau; Sample 338-20$3,54 \mathrm{~cm}$.

Figure 2 Biotite-bearing, vitric crystal basaltic ash. Irregularly shaped opaque tachylite, large platy biotite crystal fragments (upper left corner), and large, clear plagioclase crystal fragments. Oligocene; Lofoten Basin; Sample 345-21-4, 77 $\mathrm{cm}$.

Figure 3 Vitric basaltic-felsitic ash. Irregularly shaped opaque tachylite, partially opaque sideromelane shards with low to moderate vesicularity, and clear glass shards. Middle Miocene; Icelandic PlateauJan-Mayen Ridge; Sample 346-8-5, $38 \mathrm{~cm}$.

Figure $4 \quad$ Vitric felsitic ash. Clear platy glass shards, forked sponge spicule fragment. Pliocene; Icelandic Plateau-Jan-Mayen Ridge; Sample 348-8-3, 114 $\mathrm{cm}$.

Figure $5 \quad$ Vitric basaltic ash. Droplets of opaque tachylite and partially opaque, partially devitrified sideromelane, dusty and clear glass shards, blocky clinopyroxene crystal fragments; broken rodshaped sponge spicules. Pleistocene; Icelandic Plateau-Jan-Mayen Ridge; Sample 349-2-5, $55 \mathrm{~cm}$.

Figure 6 Vitric basaltic-felsitic ash. Irregularly shaped opaque tachylite, partially opaque, incipiently devitrified sideromelane, clear glass shards and pumice. Pliocene or Pleistocene; Icelandic PlateauJan-Mayen Ridge; Sample 350-2-5, $10 \mathrm{~cm}$. 
PLATE 1
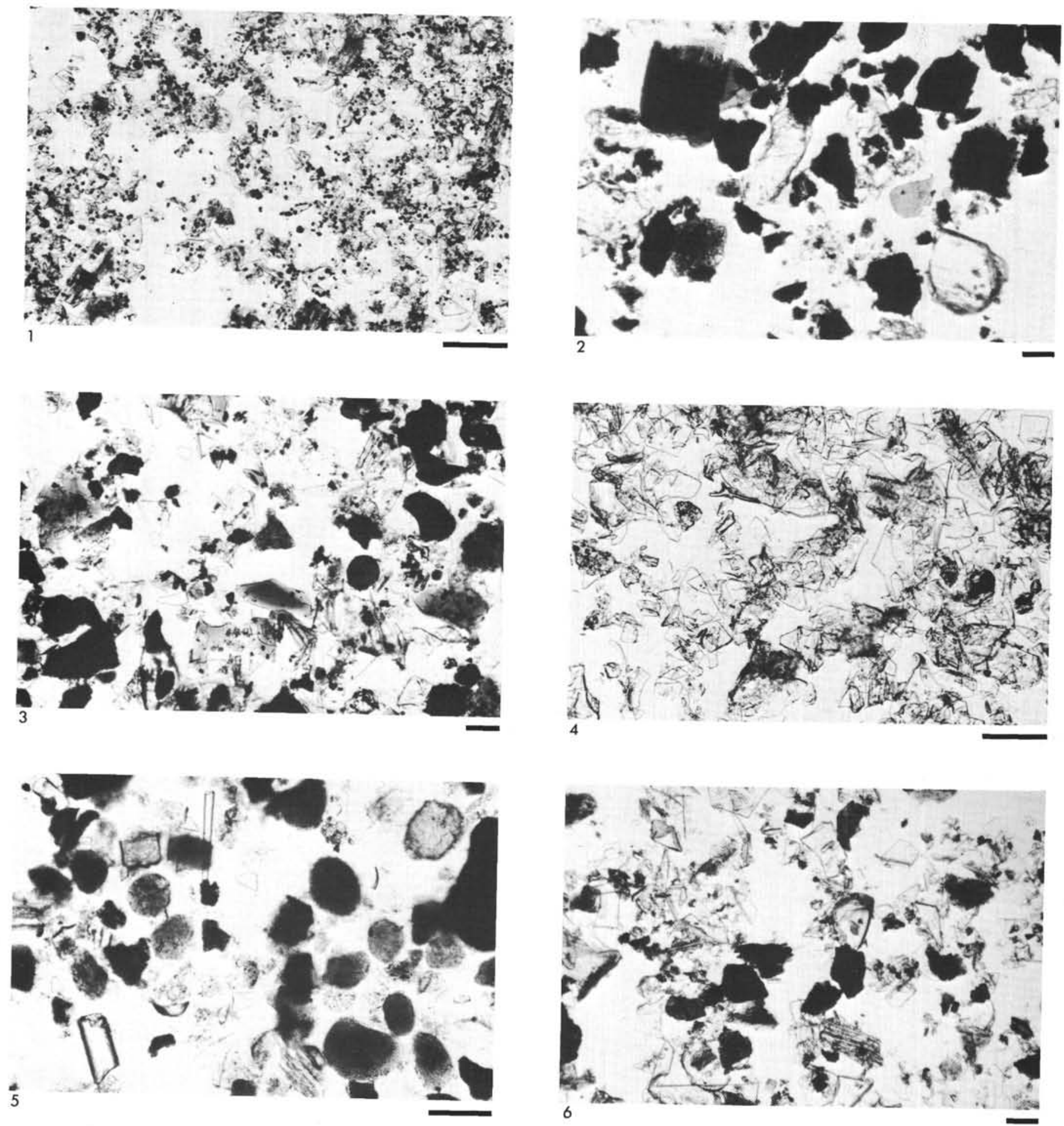